\title{
First-order linkage analysis (Frequently Applied Designs)
}

\section{AUTHOR}

Laia Castro Herrero, Theresa Gessler, Silvia Majo-Vazquez

\section{KEYWORDS}

first-order linkage analyses, content analysis, content data, survey data, mixed method, media effects, public opinion, panel data, experiments

\section{BRIEF DESCRIPTION}

First-order linkage analyses (Schulz, 2008) employ individual survey data weighted by aggregated content data and are generally used to investigate media effects on public opinion. In contrast to experiments, their outcomes are highly generalizable since they allow to grasp what kind of content people encounter in a naturalistic setting (Barabas \& Jerit, 2009), with which frequency and intensity, and how it triggers a particular reaction, attitude change, knowledge gain or behavior. First-order linkage analyses often employ manual and automated content analysis, descriptive and inferential statistical analyses. When using panel data, they are furthermore able to identify within-individual changes in attitudes and behaviors (e.g. Takens et al., 2015).

\section{FIELD OF APPLICATION/THEORETICAL FOUNDATION}

Linkage analyses have extensively been used in the fields of political communication and public opinion, EU studies and media and political psychology. Studies that employed first-order linkage analyses are concerned with theories of agenda setting (Erbring et al., 1980), visibility, priming and media attention on public opinion dynamics (e.g. Bos et al., 2011); news media tone (Hopmann et al., 2010), or the impact of exposure to counter-attitudinal views through the media (Matthes, 2012) on voting decisiveness and behavior. Framing studies or studies focusing on journalistic styles have also made extant use of linkage analysis (e.g. Jebril et al., 2013; Schuck et al., 2014) (see chapter Content Analysis in Mixed Method approaches for a detailed account of uses, applications and advantages of using linkage analyses).

\section{EXAMPLE STUDIES}

In this data entry we describe three studies that use linkage analyses to estimate (political) media effects. The first study combine survey data on people's news use with content-analyzed news stories they frequently follow to determine the impact of news tone on people's perceptions of the economy (Boomgaarden et al., 2011). The second study present more sophisticated measures of news media exposure weighted by particular content features (in casu, news tone) and also by publication recency and prominence of such content features in news stories (De Vreese et al., 2017). The third study puts forth a linkage analysis strategy using a refined media exposure measure that account for individuals' ideological distance to their frequent media diets in different polities (Castro Herrero \& Hopmann, 2017; Castro et al., 2018).

\section{REFERENCES}

Barabas, J., \& Jerit, J. (2009). Estimating the Causal Effects of Media Coverage on Policy-Specific Knowledge. American Journal of Political Science, 53(1), 73-89. https:// doi.org/10.1111/j.1540-5907.2008.00358.x

Boomgaarden, H. G., Van Spanje, J., Vliegenthart, R., \& De Vreese, C. H. (2011). Covering the crisis: Media coverage of the economic crisis and citizens' economic expectations. Acta Politica, 46(4), 353-379. 
Bos, L., Van der Brug, W., \& De Vreese, C. (2011). How the media shape perceptions of right-wing populist leaders. Political Communication, 28(2), 182-206.

Castro Herrero, L., \& Hopmann, D. N. (2017). The Virtue of Moderation: A Cross-National Analysis of Exposure to Cross-Cutting Information and Turnout. International Journal of Public Opinion Research.

Castro, L., Nir, L., \& Skovsgaard, M. (2018). Bridging Gaps in Cross-Cutting Media Exposure: The Role of Public Service Broadcasting. Political Communication, 1-24.

De Vreese, C. H., Boukes, M., Schuck, A., Vliegenthart, R., Bos, L., \& Lelkes, Y. (2017). Linking survey and media content data: Opportunities, considerations, and pitfalls. Communication Methods and Measures, 11(4), 221-244.

Erbring, L., Goldenberg, E. N., \& Miller, A. H. (1980). Front-page news and real-world cues: A new look at agenda-setting by the media. American Journal of Political Science, 16-49.

Hopmann, D. N., Vliegenthart, R., De Vreese, C., \& Alb \a ek, E. (2010). Effects of election news coverage: How visibility and tone influence party choice. Political Communication, 27(4), 389-405.
Jebril, N., Albaek, E., \& De Vreese, C. H. (2013). Infotainment, cynicism and democracy: The effects of privatization vs personalization in the news. European Journal of Communication, 28(2), 105-121.

Matthes, J. (2012). Exposure to counterattitudinal news coverage and the timing of voting decisions. Communication Research, 39(2), 147-169.

Schuck, A. R., Vliegenthart, R., \& De Vreese, C. H. (2014). Who's Afraid of Conflict? The Mobilizing Effect of Conflict Framing in Campaign News. British Journal of Political Science, 1-18.

Schulz, W. (2008). Content analyses and public opinion research. The SAGE Handbook of Public Opinion Research, 348-357.

Takens, J., Kleinnijenhuis, J., Van Hoof, A., \& Van Atteveldt, W. (2015). Party leaders in the media and voting behavior: Priming rather than learning or projection. Political Communication, 32(2), 249-267.

Vreese, C. H. D., \& Semetko, H. A. (2004). News matters: Influences on the vote in the Danish 2000 euro referendum campaign. European Journal of Political Research, 43(5), 699-722. https://doi. org/10.1111/j.0304-4130.2004.00171.x

Table 1. Data matching in correlation linkage analyses

\begin{tabular}{|c|c|c|c|c|c|}
\hline Author(s) & $\begin{array}{l}\text { Relationship } \\
\text { of theoretical } \\
\text { interest }\end{array}$ & Sample & $\begin{array}{l}\text { Time } \\
\text { frame }\end{array}$ & $\begin{array}{l}\text { Content- } \\
\text { analytical } \\
\text { constructs }\end{array}$ & Linkage strategy \\
\hline $\begin{array}{l}\text { Boom- } \\
\text { gaarden } \\
\text { et al., } \\
2011\end{array}$ & $\begin{array}{l}\text { How expo- } \\
\text { sure to me- } \\
\text { dia coverage } \\
\text { of the 2008- } \\
2009 \text { econo- } \\
\text { mic crisis } \\
\text { affected } \\
\text { expectations } \\
\text { regarding } \\
\text { the future } \\
\text { develop- } \\
\text { ment of the } \\
\text { national } \\
\text { economic } \\
\text { situation }\end{array}$ & $\begin{array}{l}\text { (a) Predictions } \\
\text { or expectations } \\
\text { about the eco- } \\
\text { nomic situations } \\
\text { provided by } \\
\text { articles of nine } \\
\text { newspapers and } \\
\text { items from } 2 \\
\text { news bulletins in } \\
\text { the Netherlands } \\
\text { in the period } \\
\text { between wave } \\
1 \text { and wave } 2 \text { of } \\
\text { the survey be- } \\
\text { low-mentioned. } \\
\text { For w2 to w3, } \\
\text { only the front }\end{array}$ & $\begin{array}{l}\text { Nov } \\
2008- \\
\text { Feb } \\
2009\end{array}$ & $\begin{array}{l}\text { "Expec- } \\
\text { tation, } \\
\text { assumption } \\
\text { or predic- } \\
\text { tion of the } \\
\text { personal } \\
\text { economic } \\
\text { situation of } \\
\text { the Dutch } \\
\text { people/ } \\
\text { the Dutch } \\
\text { economy" } \\
\text { and whet- } \\
\text { her these } \\
\text { are negati- } \\
\text { ve, neutral } \\
\text { or positive }\end{array}$ & $\begin{array}{l}\text { (1) Calculation of number } \\
\text { of positive and negative } \\
\text { economic expectations/as- } \\
\text { sumptions/predictions per } \\
\text { outlet (negative (-2), rather } \\
\text { negative (-1), balanced (0), } \\
\text { rather positive ( } 1 \text {, positive } \\
\text { (2)) for either the Dutch } \\
\text { economy or the Dutch peo- } \\
\text { ple. Negative evaluations } \\
\text { are weighted twice since } \\
\text { people tend to select nega- } \\
\text { tive information in greater } \\
\text { numbers. }\end{array}$ \\
\hline
\end{tabular}




\begin{tabular}{|c|c|c|c|c|c|}
\hline Author(s) & $\begin{array}{l}\text { Relationship } \\
\text { of theoretical } \\
\text { interest }\end{array}$ & Sample & $\begin{array}{l}\text { Time } \\
\text { frame }\end{array}$ & $\begin{array}{l}\text { Content- } \\
\text { analytical } \\
\text { constructs }\end{array}$ & Linkage strategy \\
\hline & & $\begin{array}{l}\text { pages of newspa- } \\
\text { pers were coded. } \\
\text { (b) } 976 \text { respon- } \\
\text { dents of a three- } \\
\text { wave panel sur- } \\
\text { vey conducted in } \\
\text { the Netherlands } \\
\text { between No- } \\
\text { vember } 2008 \text { to } \\
\text { February } 2009\end{array}$ & & $\begin{array}{l}\text { (Boomgaar- } \\
\text { den et al., } \\
\text { 2011, p. } \\
361 \text { ) }\end{array}$ & $\begin{array}{l}\text { (2) Each survey respon- } \\
\text { dent's frequency of use } \\
\text { of each outlet is weighted } \\
\text { (multiplied) by each outlet's } \\
\text { aggregated score for each } \\
\text { relevant content charac- } \\
\text { teristic outlined above, } \\
\text { and regressed on people's } \\
\text { actual economic expectati- } \\
\text { ons for the country and for } \\
\text { themselves. }\end{array}$ \\
\hline \multirow[t]{2}{*}{$\begin{array}{l}\text { De Vreese } \\
\text { et al. } 2017\end{array}$} & \multirow[t]{2}{*}{$\begin{array}{l}\text { How expo- } \\
\text { sure to eco- } \\
\text { nomic news } \\
\text { (visibility } \\
\text { and tone) } \\
\text { predicts } \\
\text { respondents' } \\
\text { expectati- } \\
\text { ons about } \\
\text { the state of } \\
\text { the national } \\
\text { economy in } \\
\text { the coming } \\
12 \text { months }\end{array}$} & $\begin{array}{l}\text { (a) } 1,211 \text { hand- } \\
\text { coded articles } \\
\text { evaluating the } \\
\text { state of the } \\
\text { Dutch economy } \\
\text { in } \\
\text { Dutch national } \\
\text { newspapers } \\
\text { (b) Three-wa- } \\
\text { ve panel data } \\
\text { from a surveyed } \\
\text { representative } \\
\text { sample of the } \\
\text { Dutch popula- } \\
\text { tion }\end{array}$ & $\begin{array}{l}\text { Feb- } \\
\text { June } \\
2015\end{array}$ & \multirow[t]{2}{*}{$\begin{array}{l}\text { (Negative, } \\
\text { neutral } \\
\text { or positi- } \\
\text { ve) tone } \\
\text { towards } \\
\text { the Dutch } \\
\text { economy }\end{array}$} & $\begin{array}{l}\text { (1) The authors construct a } \\
\text { variable in a content-ana- } \\
\text { lysed dataset measuring a } \\
\text { tone scale per news article, } \\
\text { ranging from - (complete- } \\
\text { ly negative) to } 2 \text { (completely } \\
\text { positive) } \\
\text { (2) Publication recency for } \\
\text { each article (how close in } \\
\text { time the article was publis- } \\
\text { hed to when respondents } \\
\text { were surveyed) and promi- } \\
\text { nence of each article (ope- } \\
\text { rationalized as how long } \\
\text { the article was compared to } \\
\text { average article length) were } \\
\text { used to create weighted } \\
\text { measures, in order to test } \\
\text { whether more recent and } \\
\text { more lengthy evaluative } \\
\text { articles had stronger effects } \\
\text { on economic perceptions, } \\
\text { as compared to an un- } \\
\text { weighted variable. }\end{array}$ \\
\hline & & & & & $\begin{array}{l}\text { (3) Observations at the } \\
\text { article level were then ag- } \\
\text { gregated at the wave-outlet } \\
\text { level in a new dataset con- } \\
\text { taining information on total } \\
\text { number of articles with } \\
\text { evaluations of the economy, } \\
\text { tone, and the two weighted } \\
\text { measures above-mentioned } \\
\text { per outlet in each wave. }\end{array}$ \\
\hline
\end{tabular}




Author(s) $\begin{aligned} & \text { Relationship Sample } \\ & \text { of theoretical } \\ & \text { interest }\end{aligned}$

Time Contentframe analytical constructs

\section{Linkage strategy}

(4) The linkage was done using the survey dataset. For each individual i in wave $\mathrm{w}$ a score of the amount of evaluative news (visibility), the positive, neutral or negative connotation of such news (tone) and the weighed variables (weighted tone by recency and prominence) was calculated for each newspaper they read on a weekly basis. The final computation can be illustrated as follows:

For each individual $i$ and wave $\mathrm{w}$,

$$
X_{i w}=\sum_{k} \delta_{i w}(k)\left(\sum_{j \in N_{k w}} y_{j}\right)
$$

Where $\mathrm{k}$ stands for outlet, $=1$ if individual i reads outlet $\mathrm{k}$ and 0 otherwise, and $\mathrm{j}$ denotes article and $\mathrm{Nkw}$ is the set of articles with evaluative news published by outlet $k$ in wave w. Yj can denote one of three possibilities:

$$
y_{j}=\left\{\begin{array}{l}
t_{j} \\
t_{j} \cdot r_{j} \\
t_{j} \cdot l_{j}
\end{array}\right.
$$

Above, tj captures tone of an article, rj captures recency and $\mathrm{l} j$ is a measure of article length.

(5) A series of OLS regression analyses were finally performed, with respondents' expectations on the economy as dependent variable, exposure to media evaluations of the econo- 


\begin{tabular}{|c|c|c|c|c|c|}
\hline Author(s) & $\begin{array}{l}\text { Relationship } \\
\text { of theoretical } \\
\text { interest }\end{array}$ & Sample & $\begin{array}{l}\text { Time } \\
\text { frame }\end{array}$ & $\begin{array}{l}\text { Content- } \\
\text { analytical } \\
\text { constructs }\end{array}$ & Linkage strategy \\
\hline & & & & & $\begin{array}{l}\text { variable, exposure to media } \\
\text { evaluations of the econo- } \\
\text { my (tone), the weighted } \\
\text { tone variables and lagged } \\
\text { dependent variables as } \\
\text { predictors. }\end{array}$ \\
\hline $\begin{array}{l}\text { Castro, } \\
\text { Nir \& } \\
\text { Skovs- } \\
\text { gaard } \\
(2018)\end{array}$ & $\begin{array}{l}\text { How politi- } \\
\text { cal interest } \\
\text { and public } \\
\text { service } \\
\text { broadcas- } \\
\text { ting strength } \\
\text { impact } \\
\text { cross-cut- } \\
\text { ting, or } \\
\text { counter-at- } \\
\text { titudinal } \\
\text { media } \\
\text { exposure; } \\
\text { and whether } \\
\text { public ser- } \\
\text { vice media } \\
\text { moderates } \\
\text { the effect } \\
\text { of political } \\
\text { interest on } \\
\text { cross-cut- } \\
\text { ting expo- } \\
\text { sure }\end{array}$ & $\begin{array}{l}\text { (a) 48,983 news } \\
\text { stories from } \\
\text { three newspa- } \\
\text { pers and two } \\
\text { TV news bulle- } \\
\text { tins across } 27 \\
\text { EU countries, } \\
\text { collected by the } \\
\text { European Elec- } \\
\text { tion Media Study } \\
\text { during the June } \\
\text { 2009 European } \\
\text { election cam- } \\
\text { paign (May } 14 \text { to } \\
\text { June } 4 \text { for some } \\
\text { countries, up to } \\
\text { May } 17 \text { to June } \\
7 \text { for others). } \\
\text { Among such sto- } \\
\text { ries, 3,390 news } \\
\text { evaluations on } \\
\text { the national } \\
\text { government's } \\
\text { record were } \\
\text { identified and } \\
\text { used to build the } \\
\text { media content } \\
\text { component of } \\
\text { a cross-cutting } \\
\text { media exposure } \\
\text { measure. } \\
\text { (b)Self-repor- } \\
\text { ted news media } \\
\text { exposure and } \\
\text { political inter- } \\
\text { est from } 27,079 \\
\text { individuals in } \\
27 \text { EU countries } \\
\text { surveyed by } \\
\text { the European }\end{array}$ & $\begin{array}{l}\text { May- } \\
\text { June } \\
2009\end{array}$ & $\begin{array}{l}\text { Tone } \\
\text { toward the } \\
\text { national } \\
\text { govern- } \\
\text { ment (posi- } \\
\text { tive (1), } \\
\text { balanced/ } \\
\text { mixed (0), } \\
\text { negative } \\
(-1)\end{array}$ & $\begin{array}{l}\text { (1) A variable that accounts } \\
\text { for the extent to which an } \\
\text { individual approves (1) or } \\
\text { disapproves (- 1) of the } \\
\text { government's performance } \\
\text { to date is built. } \\
\text { (2) The mean of each natio- } \\
\text { nal government' s positive } \\
\text { (1), balanced/mixed (0), or } \\
\text { negative (- 1) evaluations } \\
\text { found in each media outlet' } \\
\text { s news stories is computed. } \\
\text { (3) Cross-cutting exposure } \\
\text { is calculated by accounting } \\
\text { for the absolute difference } \\
\text { between each individual's } \\
\text { approval of their govern- } \\
\text { ment and the average de- } \\
\text { gree for each media outlet } \\
\text { this individual uses at least } \\
\text { once a week, averaged by } \\
\text { the number of news } \\
\text { media outlets they follow. } \\
\text { (4) Random-intercept } \\
\text { regression models, using } \\
\text { individual exposure to } \\
\text { cross-cutting information } \\
\text { as the dependent variab- } \\
\text { le, and political interest, } \\
\text { public service broadcasting } \\
\text { strength (audience share) } \\
\text { and an interaction between } \\
\text { both as main independent } \\
\text { variables, are run. This } \\
\text { allows to account for the } \\
\text { hierarchical structure of } \\
\text { the data by decomposing } \\
\text { individual and country-le- } \\
\text { vel variances, and also to } \\
\text { explain the relationship } \\
\text { between cross-cutting news }\end{array}$ \\
\hline
\end{tabular}




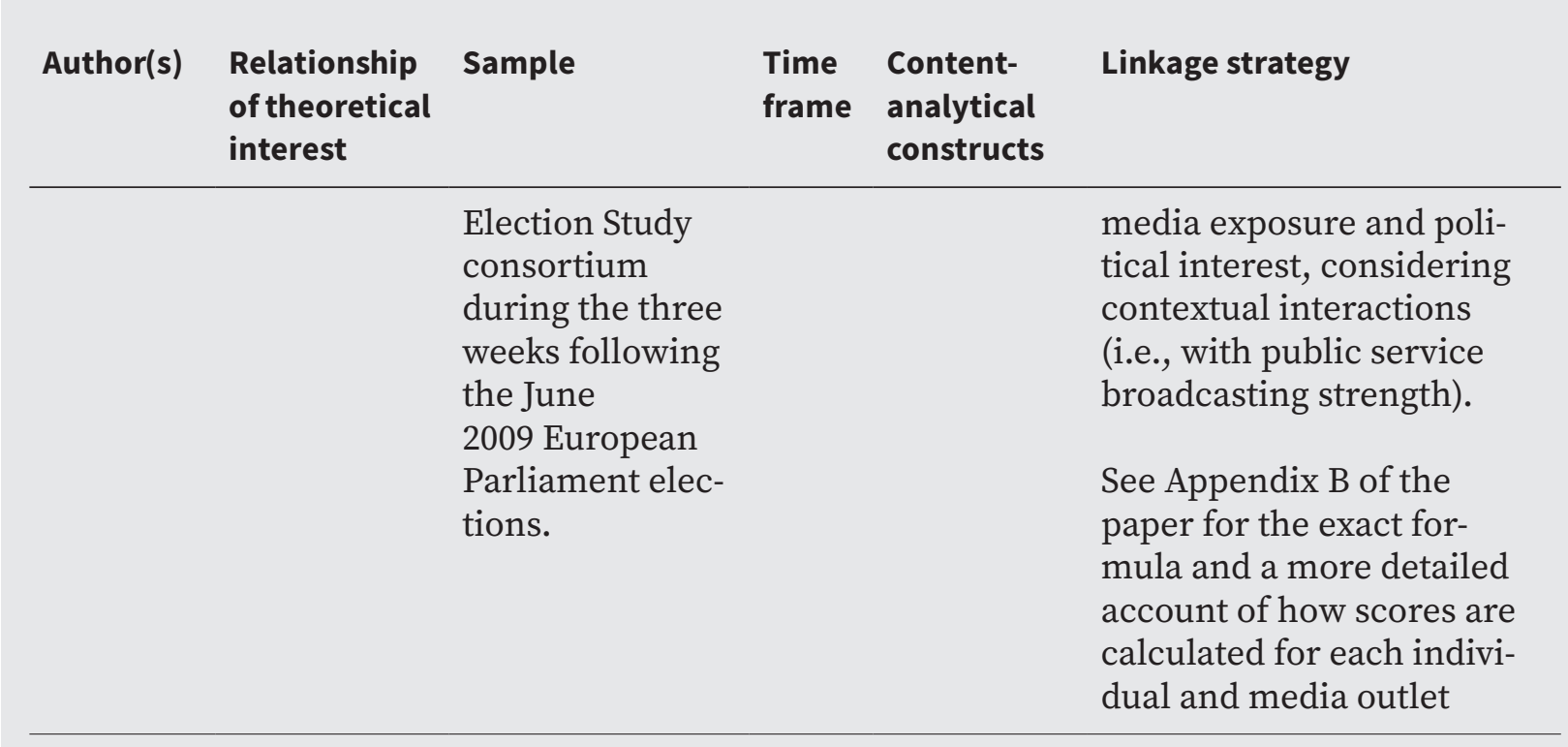

